\title{
Associations between short-term exposure to gaseous pollutants and pulmonary heart disease-related mortality among elderly people in Chengdu, China
}

\author{
Jianyu Chen ${ }^{1}$, Jie Zeng ${ }^{1}$, Chunli Shi', Ruicong Liu', Rong Lu², Suling Mao ${ }^{1 *}$ and Li Zhang ${ }^{1 *}$ (D)
}

\begin{abstract}
Background: Pulmonary heart disease (PHD) has become a global burden, especially in low- and middle-income countries. However, very few studies have assessed the influence of air pollution on PHD. This is the first study to explore the association between gaseous pollutants and PHD-related mortality in the central Sichuan Basin of southwestern China.

Methods: Data on PHD-related mortality among elderly people (aged 60 and older) from 2013 to 2017 were collected from the Population Death Information Registration and Management System (PDIRMS). Data on air pollutants were collected from all 24 Municipal Environmental Monitoring Sites in Chengdu, and data on daily temperature, relative humidity, and atmospheric pressure were collected from the Chengdu Municipal Meteorological Bureau. An epidemiological design of time-stratified case-crossover was conducted to assess the association between short-term exposure to ambient gaseous pollutants and PHD-related mortality among elderly people.

Results: About 54,920 PHD-related deaths among people aged 60 and older were reported. After controlling for daily temperature, relative humidity, and atmospheric pressure, an IQR concentration increase in levels of sulfur dioxide $\left(\mathrm{SO}_{2}\right)\left(13 \mu \mathrm{g} / \mathrm{m}^{3}\right)$, nitrogen dioxide $\left(\mathrm{NO}_{2}\right)\left(17 \mu \mathrm{g} / \mathrm{m}^{3}\right)$, and ozone $\left(\mathrm{O}_{3}\right)\left(74 \mu \mathrm{g} / \mathrm{m}^{3}\right)$ was associated with $7.8,6.2$, and $5.5 \%$ increases in PHD-related mortality in people aged 60 and older, respectively. People over age 70 might have even higher susceptibility to PHD-related mortality associated with $\mathrm{SO}_{2}, \mathrm{NO}_{2}$, and $\mathrm{O}_{3}$. Females and individuals with alternative marital statuses (widowed, divorced, or never married) had twice and more than twice the PHD-related mortality risk associated with $\mathrm{SO}_{2}$ and $\mathrm{NO}_{2}$ than males and married individuals, respectively.

Conclusions: Increased concentrations of ambient $\mathrm{SO}_{2}, \mathrm{NO}_{2}$, and $\mathrm{O}_{3}$ were significantly and positively associated with PHD-related mortality in Chengdu, China. Sociodemographic factors - including gender, age, and marital status - may modify the acute health effects of gaseous pollutants.
\end{abstract}

Keywords: Air pollution, Basin, Pulmonary heart disease-related mortality, Elderly people, Time-stratified case-crossover

\footnotetext{
*Correspondence: 465842656@qq.com; 657096242@qq.com

${ }^{1}$ Sichuan Provincial Center for Disease Control and Prevention, No.6,

Zhongxue Road, Wuhou District, Chengdu 610041, China

Full list of author information is available at the end of the article
}

(c) The Author(s). 2019 Open Access This article is distributed under the terms of the Creative Commons Attribution 4.0 International License (http://creativecommons.org/licenses/by/4.0/) which permits unrestricted use, distribution, and reproduction in any medium, provided you give appropriate credit to the original author(s) and the source, provide a link to the Creative Commons license, and indicate if changes were made. The Creative Commons Public Domain Dedication waiver (http://creativecommons.org/publicdomain/zero/1.0/) applies to the data made available in this article, unless otherwise stated. 


\section{Background}

Pulmonary heart disease (PHD) was once described as the overall condition of the right heart from the time it is first affected by pulmonary disease to the final failure [1]. More recently, this definition has been expanded to account for pulmonary arterial hypertension resulting from diseases affecting the structure and/or the function of the lungs. Pulmonary arterial hypertension results in right ventricular enlargement (hypertrophy and/or dilatation) and over time may lead to right heart failure [2]. PHD has emerged as a major cause of disability and mortality within cardiovascular diseases [3]. In the United States, PHD is estimated to account for 7 to $10 \%$ of all heart diseases, and to be associated with between 10 and $30 \%$ of all hospital admissions for heart failure [4]. Autopsy studies in patients who died of chronic lung disease found that $40 \%$ were accompanied with PHD anatomically [5]. PHD has sharply become a global burden, especially in low- and middle-income countries (LMICs) [6]. In developing countries, 20-25 million people have some form of pulmonary vascular disease, which is a much larger number than in the developed world [7].

In recent years, numerous studies were conducted to explore the association between air pollution and cardiovascular disease $[8,9]$; these studies focused on coronary heart disease [10], heart failure [11], myocardial infarction [12], and other conditions. However, very few studies assessed the influence of air pollution on PHD. In 1993, by recruiting a study group of 30 patients in Mexico city, Julio Sandoval, et al. [13] found associations between pulmonary arterial hypertension, cor pulmonale, and long-term exposure to domestic wood smoke. In Turkey, research exploring associations between exposure to biomass smoke and tobacco smoke and frequency of pulmonary hypertension in patients with chronic obstructive pulmonary disease (COPD) was conducted from 2000 to 2010 [14].

In light of these previous findings, our study was conducted to (1) assess the association between short-term exposure to ambient gaseous pollutants $\left(\mathrm{SO}_{2}, \mathrm{NO}_{2}\right.$, carbon monoxide $(\mathrm{CO})$, and $\mathrm{O}_{3}$ ) and PHD-related mortality in people aged 60 and older and (2) determine the modifying effects of sociodemographic factors (e.g., age, gender, and marital status) on PHD-related mortality due to gaseous pollutants.

We conducted our study in Chengdu city, which is in the central Sichuan Basin, China. The Sichuan Basin, a typical basin in southwest China, exhibits severe air pollution [15]. Chengdu city is densely populated with over 15 million people [16]. Therefore, the city is well suited for such a time series study. To our knowledge, no similar reports regarding to the association between ambient gaseous pollutants and PHD-related mortality have come from studies conducted in this region. Thus, ours may fill a gap in knowledge on this topic. An epidemiological design of time-stratified case-crossover was conducted to assess the association between short-term exposure to ambient gaseous pollutants and PHDrelated mortality among elderly people in the central $\mathrm{Si}$ chuan Basin of China.

\section{Methods \\ Data collection}

Data on mortality were collected from the Population Death Information Registration and Management System (PDIRMS), which covers all 20 districts in Chengdu. The death of a resident was confirmed by a hospital or by doctors at the resident's home; the data on the death were recorded in the system afterwards. A complete record includes name, ID number, gender, nation, marital status, residential address, birth date, date of death, location of death, primary diagnosis for death, second diagnosis for death, and other information. We omitted information that could be used to identify a subject, such as name, ID number, and residential address. Gender, age, and marital status were retained for further analysis. All death records were obtained from the system from January 1, 2013 to December 31, 2017, and records were extracted for further study only if they fulfilled two criteria:)1) if the subject's age was 60 or older and (2) if the primary diagnosis of death was PHD. The International Classification of Disease, 10th Revision (ICD-10), was used to diagnose PHD (ICD-10 code I27) and related conditions, which included I27.0 (primary pulmonary hypertension), I27.1 (kyphoscoliotic heart disease), I27.2 (other secondary pulmonary hypertension), I27.8 (other specified pulmonary heart diseases), and I27.9 (pulmonary heart disease, unspecified). Pulmonary embolism (ICD-10 code I26) and other diseases of the pulmonary vessels (ICD-10 code I28) were excluded in our study.

Data on air pollutants - including $\mathrm{SO}_{2}, \mathrm{NO}_{2}, \mathrm{CO}$, daily eight-hour mean concentrations of $\mathrm{O}_{3}(\mathrm{O} 3-8 \mathrm{~h})$, and particulate matter less than $2.5 \mu \mathrm{m}$ in aerodynamic diameter $\left(\mathrm{PM}_{2.5}\right)$ - were collected from all 24 Municipal Environmental Monitoring Sites in Chengdu from January 1, 2013 to December 31, 2017 (Fig. 1). Concentrations of air pollutants were continuously monitored $24 \mathrm{~h}$ a day, and the data were recorded in the system automatically in every fixed monitoring site. Daily mean concentrations of $\mathrm{SO}_{2}, \mathrm{NO}_{2}, \mathrm{CO}, \mathrm{PM}_{2.5}$, and $\mathrm{O}_{3}-8$ h were calculated using each pollutant's data from all 24 sites. Daily 8-h mean concentrations of $\mathrm{O}_{3}$ were defined as the highest moving 8-h mean concentrations for $\mathrm{O}_{3}$ per day [17]. Missing data of concentrations from one or more sites on a given day were acceptable, and the data from the remaining sites were calculated as mean concentrations for exposure. Weather conditions were considered confounders and needed to be controlled adequately [18]. Data on daily temperature, relative humidity, and 


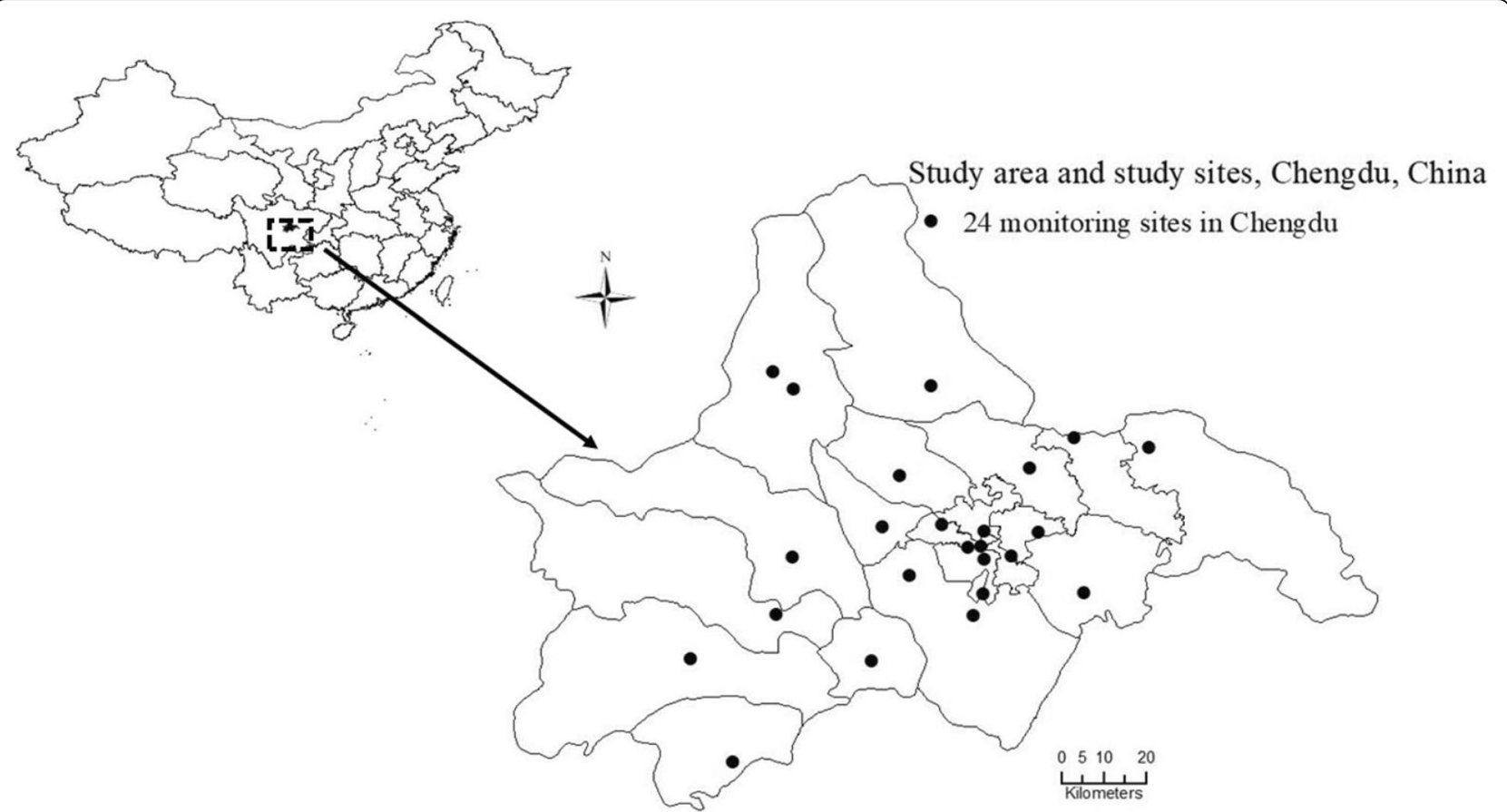

Fig. 1 Study area and study locations within the city of Chengdu, China. The enlarged area depicts the spatial distribution of the 24 municipal environmental monitoring sites throughout Chengdu

atmospheric pressure were collected from the Chengdu Municipal Meteorological Bureau from January 1, 2013 to December 31, 2017.

\section{Statistical analysis}

Spearman's correlation analysis was used to explore correlations between air pollutants and weather conditions. A method of time-stratified case-crossover was conducted to estimate the association between gaseous pollutants and PHD-related mortality [19, 20]. In using the method of case-crossover, one subject served as both cases and his or her own controls at the same time. In this way, the influences related to individual characteristics - such as age, gender, body mass index, and occupational hazards - could be controlled. The time-stratified method controlled influences such as long-term trends, seasonal patterns, and days of the week by restricting case and controls to the same weekday within the same month and year. The time span between case and controls was limited so that the long-term trends and seasonal patterns would be controlled. Setting control days as the same weekdays mitigated the influence of the day of the week. The number of controls varied between 3 and 4 according to the number of days in the month [21]. For example, if one subject died from PHD on Monday, March 10, 2014, the case day was defined as the same day and the control days were defined as all the remaining Mondays in March 2014 (March 3, 17, 24, and 31), which meant there would be four controls as opposed to only one case.

Delayed effects could exist between exposure to gaseous pollutants and health outcomes [22, 23]. Exposure on a given day could result in death a few days later. To explore the delayed effects, we employed a single-day lag model and the lag days were set from 1 up to 5 prior to the case day.

Weather conditions as confounders - including daily temperature, relative humidity, and atmospheric pressure - were controlled in all models by using natural cubic splines (ns) with three degrees of freedom [24].

The statistical significance of the differences between effect estimates of the strata of a potential effect modifier (e.g. the difference between "male" and "female") was tested by calculating the $95 \%$ confidence interval $(95 \% \mathrm{CI})$. The equation was $\left(\hat{Q}_{1}-\hat{Q}_{2}\right) \pm 1.96 \sqrt{S \hat{E}_{1}^{2}+S \hat{E}_{2}^{2}}$, where $\hat{Q}_{1}$ and $\hat{Q}_{2}$ were the estimates for the two categories and $S \hat{E}_{1}$ and $\mathrm{SE}_{2}$ were their respective standard errors [25].

Sensitivity analyses were performed in two manners to estimate the robustness of results. First, a two-pollutant model was conducted for pollutants with statistically significant associations with PHD-related mortality. Second, a different lag structure of the multi-day moving average of pollutant concentrations on the case day and up to 3 days prior (Lag01, Lag02, and Lag03, 
respectively) was conducted for pollutants with statistically significant associations with PHD-related mortality.

The results were calculated as an odds ratio (OR) with a 95\% confidence interval (CI) for an interquartile range (IQR) increase in each pollutant. The "Season" package in $\mathrm{R}$ (version 3.5.1) was used for fitting the timestratified case-crossover model [19].

\section{Results}

54,920 PHD-related deaths at age 60 and older were collected from January 1, 2013 to December 31, 2017. 28, 971 of the subjects were male and 25,949 were female. 27,424 of the subjects were married and 27,496 were held alternative statuses, including widowed, divorced, and never married. The mean number of daily deaths was 30.1 , while the maximum and minimum were 109 and 4, respectively. The mean concentrations of $\mathrm{SO}_{2}$, $\mathrm{NO}_{2}, \mathrm{CO}, \mathrm{O}_{3}-8 \mathrm{~h}$, and $\mathrm{PM}_{2.5}$ were 21.6, 41.5, 1124.2, 92.4 , and $70.5 \mu \mathrm{g} / \mathrm{m}^{3}$, respectively, while increases in their IQRs were $13,17,498,74$, and $53 \mu \mathrm{g} / \mathrm{m}^{3}$, respectively. The mean daily temperature, relative humidity, and atmospheric pressure were $17.0^{\circ} \mathrm{C}, 77.7 \%$, and 951.7 hpa, respectively (Table 1).

Table 2 shows the Spearman's correlation coefficients of air pollutants and weather conditions. The correlations existed among air pollutants, and between air pollutants and weather conditions. Additionally, correlations of air pollutants existed between each pair of individual sites (Additional file 1: Table S1). Concentrations of $\mathrm{SO}_{2}, \mathrm{NO}_{2}$, $\mathrm{CO}$, and $\mathrm{PM}_{2.5}$ were remarkably higher in winter than those in summer, while concentrations of $\mathrm{O}_{3}$ were contrary (Additional file 2: Figure S1).

Figure 2 shows the calculated results of association between PHD-related mortality in people aged 60 years and older and ambient gaseous pollutants. After controlling the influence of confounders - including daily temperature, relative humidity, and atmospheric pressure - the associations were between PHD-related mortality in people aged 60 years and older and increases in concentration of IQR in $\mathrm{SO}_{2}\left(13 \mu \mathrm{g} / \mathrm{m}^{3}\right), \mathrm{NO}_{2}\left(17 \mu \mathrm{g} / \mathrm{m}^{3}\right)$, and $\mathrm{O}_{3}\left(74 \mu \mathrm{g} / \mathrm{m}^{3}\right)$. The days corresponding to the greatest effects for $\mathrm{SO}_{2}, \mathrm{NO}_{2}$, and $\mathrm{O}_{3}$ were one, one-, and two-day lags, respectively. The association between PHD-related mortality in people aged 60 years and older and $\mathrm{CO}$ was not observed. Additionally, an association between PHD-related mortality in people aged 60 years and older and $\mathrm{PM}_{2.5}$ was observed in our study. The day corresponding to the greatest effect was one-day lag (Table 3).

Associations between PHD-related mortality in people age 60 years and older and gaseous pollutants varied

Table 1 Data of air pollutants, weather conditions, and deaths from PHD from 2013 to 2017

\begin{tabular}{|c|c|c|c|c|c|c|c|c|}
\hline & Mean & SD & Min. & $25 \%$ & $50 \%$ & $75 \%$ & Max. & IQR \\
\hline $\mathrm{SO}_{2}\left(\mu \mathrm{g} / \mathrm{m}^{3}\right)$ & 21.6 & 10.5 & 6.0 & 14.0 & 20.0 & 27.0 & 71.0 & 13.0 \\
\hline $\mathrm{NO}_{2}\left(\mu \mathrm{g} / \mathrm{m}^{3}\right)$ & 41.5 & 13.2 & 13.0 & 32.0 & 39.0 & 49.0 & 89.0 & 17.0 \\
\hline $\mathrm{CO}\left(\mu \mathrm{g} / \mathrm{m}^{3}\right)$ & 1124.2 & 790.2 & 425.0 & 787.0 & 987.0 & 1285.0 & $16,608.0$ & 498.0 \\
\hline $\mathrm{O}_{3}-8 \mathrm{~h}\left(\mu \mathrm{g} / \mathrm{m}^{3}\right)$ & 92.4 & 49.6 & 11.0 & 54.0 & 82.0 & 128.0 & 285.0 & 74.0 \\
\hline $\mathrm{PM}_{2.5}\left(\mu \mathrm{g} / \mathrm{m}^{3}\right)$ & 70.5 & 48.9 & 9.0 & 36.0 & 56.0 & 89.0 & 372.0 & 53.0 \\
\hline Temperature $\left({ }^{\circ} \mathrm{C}\right)$ & 17.0 & 7.2 & -1.9 & 10.3 & 17.9 & 23.2 & 30.0 & 12.9 \\
\hline Humidity (\%) & 77.7 & 9.7 & 41.0 & 72.0 & 78.0 & 85.0 & 98.0 & 13.0 \\
\hline AP (hpa) & 951.7 & 7.4 & 933.1 & 945.6 & 951.2 & 957.4 & 977.3 & 11.8 \\
\hline Deaths from PHD & 30.1 & 16.7 & 4 & 19 & 25 & 37 & 109 & 18 \\
\hline \multicolumn{9}{|l|}{ Age groups (year) } \\
\hline $60-69$ & 3.3 & 2.6 & 0 & 2 & 3 & 4 & 18 & 2 \\
\hline $70-79$ & 8.8 & 5.5 & 0 & 5 & 7.5 & 11 & 44 & 6 \\
\hline $80-89$ & 13.5 & 8.0 & 1 & 8 & 11 & 17 & 56 & 9 \\
\hline $90-$ & 4.5 & 3.7 & 0 & 2 & 4 & 6 & 25 & 4 \\
\hline \multicolumn{9}{|l|}{ Gender } \\
\hline Male & 15.9 & 9.6 & 1 & 10 & 13 & 19 & 69 & 9 \\
\hline Female & 14.2 & 8.2 & 1 & 9 & 12 & 18 & 57 & 9 \\
\hline \multicolumn{9}{|l|}{ Marital status } \\
\hline Married & 15.0 & 8.8 & 1 & 9 & 13 & 18 & 63 & 9 \\
\hline Alternative status ${ }^{\mathrm{a}}$ & 15.1 & 9.1 & 1 & 9 & 13 & 18 & 67 & 9 \\
\hline
\end{tabular}

${ }^{a}$ Alternative marital statuses include widowed, divorced, and never married

Abbreviations: $\mathrm{SO}_{2}$ sulfur dioxide, $\mathrm{NO}_{2}$ nitrogen dioxide, $\mathrm{CO}$ carbon monoxide, $\mathrm{O}_{3}-8 \mathrm{~h}$ daily eight-hour mean concentration of $\mathrm{O}_{3}, P M_{2.5}$ particulate matter less than $2.5 \mu \mathrm{m}$ in aerodynamic diameter, $A P$ atmospheric pressure, $P H D$ pulmonary heart disease, $S D$ standard deviation, $I Q R$ inter-quartile range 
Table 2 Spearman's correlation coefficients of air pollutants and weather conditions

\begin{tabular}{|c|c|c|c|c|c|c|c|c|}
\hline & $\mathrm{SO}_{2}$ & $\mathrm{NO}_{2}$ & $\mathrm{CO}$ & $\mathrm{O}_{3}$ & $\mathrm{PM}_{2.5}$ & Temperature & Humidity & $\mathrm{AP}$ \\
\hline$\overline{\mathrm{SO}_{2}}$ & 1 & & & & & & & \\
\hline $\mathrm{NO}_{2}$ & $0.474^{a}$ & 1 & & & & & & \\
\hline $\mathrm{CO}$ & $0.615^{a}$ & $0.678^{a}$ & 1 & & & & & \\
\hline $\mathrm{O}_{3}$ & $-0.047^{\mathrm{a}}$ & $-0.195^{\mathrm{a}}$ & $-0.383^{a}$ & 1 & & & & \\
\hline $\mathrm{PM}_{2.5}$ & $0.622^{a}$ & $0.785^{a}$ & $0.817^{a}$ & $-0.205^{a}$ & 1 & & & \\
\hline Temperature & $-0.084^{a}$ & $-0.431^{\mathrm{a}}$ & $-0.474^{\mathrm{a}}$ & $0.680^{a}$ & $-0.462^{a}$ & 1 & & \\
\hline Humidity & $-0.446^{a}$ & $-0.137^{\mathrm{a}}$ & $-0.058^{a}$ & $-0.428^{a}$ & $-0.190^{a}$ & $-0.078^{a}$ & 1 & \\
\hline $\mathrm{AP}$ & $0.079^{a}$ & $0.365^{a}$ & $0.363^{a}$ & $-0.596^{a}$ & $0.335^{\mathrm{a}}$ & $-0.851^{\mathrm{a}}$ & -0.002 & 1 \\
\hline
\end{tabular}

${ }^{\mathrm{a}} P<0.05$

Abbreviations: $\mathrm{SO}_{2}$ sulfur dioxide, $\mathrm{NO}_{2}$ nitrogen dioxide, $\mathrm{CO}$ carbon monoxide, $\mathrm{O}_{3}$ ozone, $P M_{2.5}$ particulate matter less than $2.5 \mu \mathrm{m}$ in aerodynamic diameter; AP, atmospheric pressure

according to age group. The associations were found in age groups 70 to 79,80 to 89 , and 90 and above, while no association was observed in the age group 60 to 69 . The greatest effects for $\mathrm{SO}_{2}, \mathrm{NO}_{2}$, and $\mathrm{O}_{3}$ in age group 70 to 79 were at Lag1 $(\mathrm{OR}=1.106,95 \% \mathrm{CI}: 1.060-$ 1.155), Lag1 (OR $=1.065,95 \% \mathrm{CI}: 1.035-1.095)$, and Lag2 (OR $=1.089,95 \% \mathrm{CI}: 1.043-1.137)$; in age group 80 to 89 these were at Lag1 $(\mathrm{OR}=1.069,95 \% \mathrm{CI}: 1.032-$ 1.107), Lag2 (OR=1.060, 95\% CI: 1.036-1.085), and Lag2 $(\mathrm{OR}=1.043,95 \% \mathrm{CI}: 1.008-1.081)$; and in age group 90 and above these were at Lag1 (OR $=1.077,95 \%$ CI: 1.011-1.147), Lag1 (OR $=1.092$, 95\% CI: 1.049-
1.137), and Lag3 (OR =1.063, 95\% CI: 1.002-1.127) (Fig. 3).

For $\mathrm{SO}_{2}, \mathrm{NO}_{2}$, and $\mathrm{O}_{3}, \mathrm{ORs}$ in female subjects were 1.106 (95\% CI: 1.069-1.144), 1.084 (95\% CI: $1.060-$ 1.109 ), and 1.075 (95\% CI: 1.039-1.113), respectively; in male subjects these were 1.052 (95\% CI: 1.019-1.088), 1.042 (95\% CI: 1.020-1.065), and 1.053 (95\% CI: $1.017-$ 1.091), respectively; in those with alternative marital statuses (widowed, divorced, or never married) these were 1.107 (95\% CI: 1.071-1.144), 1.088 (95\% CI: 1.0651.112), and 1.055 (95\% CI: 1.021-1.091), respectively; and in married individuals these were 1.051 (95\% CI:

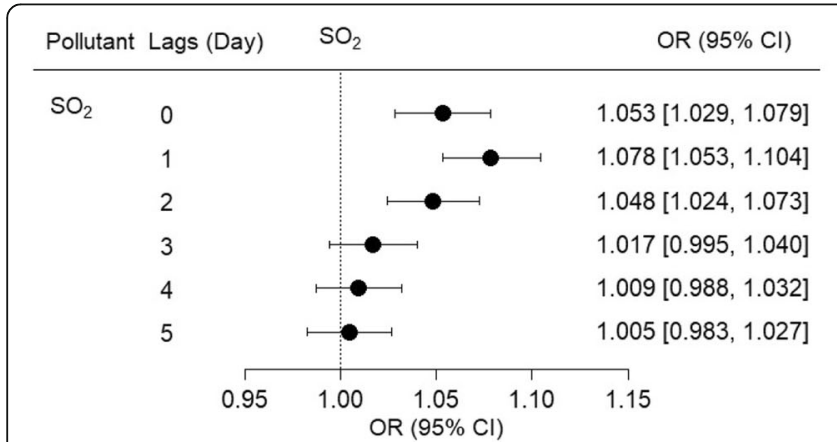
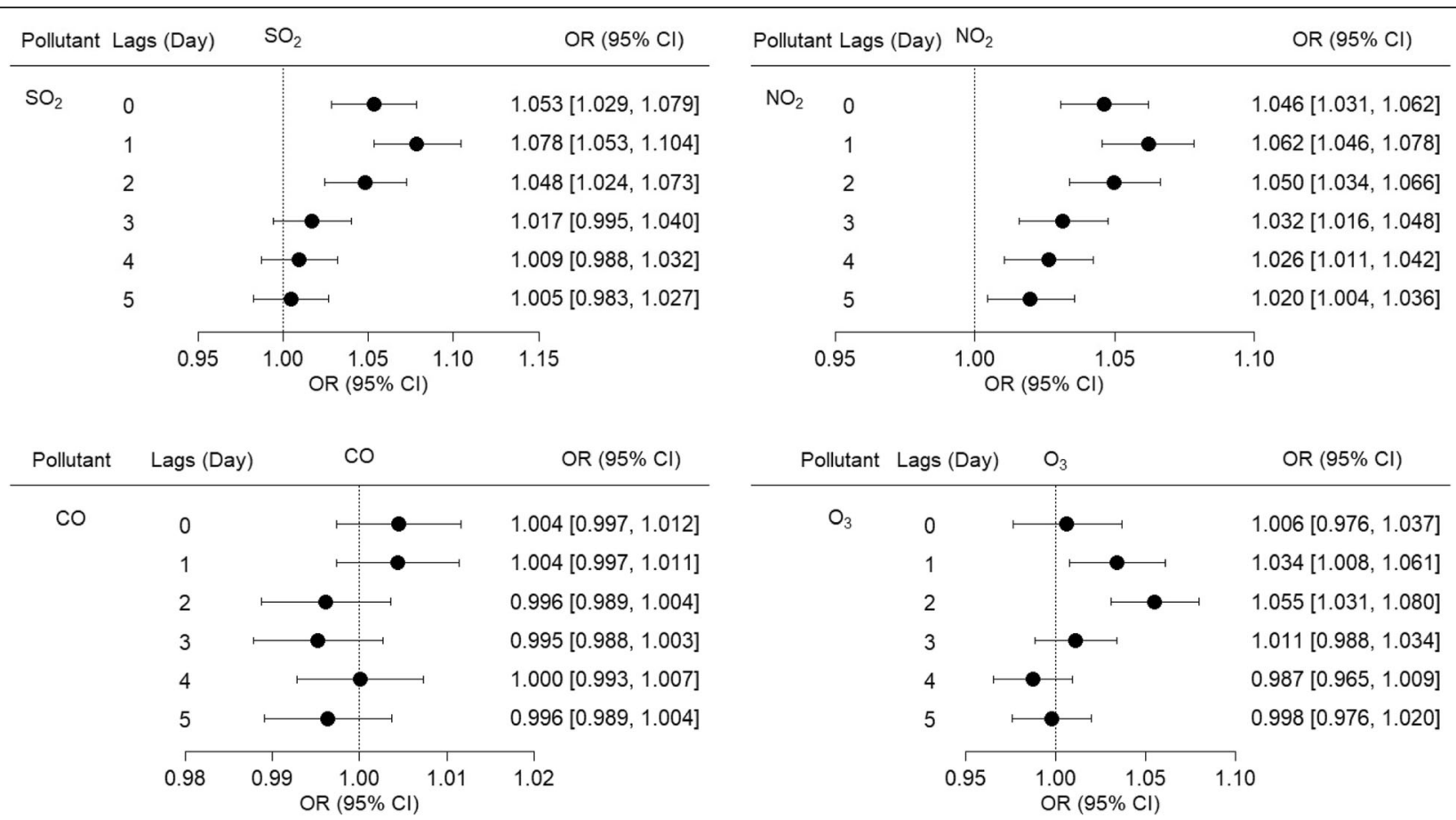

Fig. 2 Association between PHD-related mortality among elderly people and IQR increases for $\mathrm{SO}_{2}, \mathrm{NO}_{2}$, $\mathrm{CO}$, and $\mathrm{O}_{3}$ over Lag 0 to Lag 5 days. All models were adjusted for temperature, relative humidity, and atmospheric pressure 
Table 3 Odds ratios calculated via different lag-day model structures

\begin{tabular}{|c|c|c|c|c|}
\hline \multirow{2}{*}{$\begin{array}{l}\text { Air } \\
\text { pollutants }\end{array}$} & \multirow{2}{*}{$\begin{array}{l}\text { Lag } \\
\text { (days) }\end{array}$} & \multirow[t]{2}{*}{ OR } & \multicolumn{2}{|c|}{ OR 95\% Cl } \\
\hline & & & Lower & $\overline{\text { upper }}$ \\
\hline \multirow[t]{7}{*}{$\overline{\mathrm{SO}_{2}}$} & 0 & $1.053^{a}$ & 1.029 & 1.079 \\
\hline & 1 & $1.078^{a}$ & 1.053 & 1.104 \\
\hline & 2 & $1.048^{a}$ & 1.024 & 1.073 \\
\hline & 3 & 1.017 & 0.995 & 1.040 \\
\hline & 01 & $1.086^{\mathrm{a}}$ & 1.057 & 1.116 \\
\hline & 02 & $1.095^{\mathrm{a}}$ & 1.064 & 1.128 \\
\hline & 03 & $1.090^{\mathrm{a}}$ & 1.056 & 1.124 \\
\hline \multirow[t]{7}{*}{$\mathrm{NO}_{2}$} & 0 & $1.046^{\mathrm{a}}$ & 1.031 & 1.062 \\
\hline & 1 & $1.062^{\mathrm{a}}$ & 1.046 & 1.078 \\
\hline & 2 & $1.050^{\mathrm{a}}$ & 1.034 & 1.066 \\
\hline & 3 & $1.032^{\mathrm{a}}$ & 1.016 & 1.048 \\
\hline & 01 & $1.064^{\mathrm{a}}$ & 1.047 & 1.082 \\
\hline & 02 & $1.074^{\mathrm{a}}$ & 1.054 & 1.093 \\
\hline & 03 & $1.077^{\mathrm{a}}$ & 1.056 & 1.098 \\
\hline \multirow[t]{7}{*}{$\mathrm{CO}$} & 0 & 1.004 & 0.997 & 1.012 \\
\hline & 1 & 1.004 & 0.997 & 1.011 \\
\hline & 2 & 0.996 & 0.989 & 1.004 \\
\hline & 3 & 0.995 & 0.988 & 1.003 \\
\hline & 01 & 1.008 & 0.998 & 1.017 \\
\hline & 02 & 1.004 & 0.993 & 1.015 \\
\hline & 03 & 1.000 & 0.988 & 1.013 \\
\hline \multirow[t]{7}{*}{$\mathrm{O}_{3}$} & 0 & 1.006 & 0.976 & 1.037 \\
\hline & 1 & $1.034^{\mathrm{a}}$ & 1.008 & 1.061 \\
\hline & 2 & $1.055^{\mathrm{a}}$ & 1.031 & 1.080 \\
\hline & 3 & 1.011 & 0.988 & 1.034 \\
\hline & 01 & $1.037^{\mathrm{a}}$ & 1.000 & 1.074 \\
\hline & 02 & $1.076^{\mathrm{a}}$ & 1.036 & 1.117 \\
\hline & 03 & $1.070^{a}$ & 1.029 & 1.113 \\
\hline \multirow[t]{7}{*}{$\mathrm{PM}_{2.5}$} & 0 & $1.032^{a}$ & 1.018 & 1.047 \\
\hline & 1 & $1.038^{a}$ & 1.023 & 1.053 \\
\hline & 2 & $1.028^{a}$ & 1.013 & 1.042 \\
\hline & 3 & 1.013 & 0.999 & 1.027 \\
\hline & 01 & $1.042^{\mathrm{a}}$ & 1.026 & 1.058 \\
\hline & 02 & $1.045^{\mathrm{a}}$ & 1.027 & 1.062 \\
\hline & 03 & $1.043^{\mathrm{a}}$ & 1.025 & 1.062 \\
\hline
\end{tabular}

Abbreviations: $\mathrm{SO}_{2}$ sulfur dioxide, $\mathrm{NO}_{2}$ nitrogen dioxide, $\mathrm{CO}$ carbon monoxide, $\mathrm{O}_{3}$ ozone, $P M_{2.5}$ particulate matter less than $2.5 \mu \mathrm{m}$ in aerodynamic diameter, $O R$ odds ratio, $\mathrm{Cl}$ confidence interval

${ }^{\mathrm{a}} P<0.05$

1.016-1.086), 1.036 (95\% CI: 1.013-1.059), and 1.055 (95\% CI: 1.020-1.090), respectively. In the cases of $\mathrm{SO}_{2}$ and $\mathrm{NO}_{2}$, significant statistical differences in the effect estimates existed between females and males and between alternative marital status individuals and married individuals. However, in the case of $\mathrm{O}_{3}$, differences between females and males and between alternative marital status individuals and married individuals were not observed (Fig. 4).

For $\mathrm{SO}_{2}, \mathrm{NO}_{2}$, and $\mathrm{O}_{3}$, corresponding to their greatest effective days $\left(\mathrm{SO}_{2}\right.$ at Lag1, $\mathrm{NO}_{2}$ at Lag1, and $\mathrm{O}_{3}$ at Lag2, respectively), we applied a two-pollutant model by adding $\mathrm{PM}_{2.5}, \mathrm{SO}_{2}, \mathrm{NO}_{2}, \mathrm{O}_{3}$, and $\mathrm{CO}$ as co-variants, respectively. The health effects of $\mathrm{SO}_{2}, \mathrm{NO}_{2}$ and $\mathrm{O}_{3}$ mainly remained in two- pollutant models, although the effects of $\mathrm{SO}_{2}$ became null after adjusting for $\mathrm{NO}_{2}$ (Table 4).

\section{Discussion}

In using the method of time-stratified case-crossover, we determined a significantly positive association between PHD-related mortality in people aged 60 and older and gaseous pollutants in Chengdu, China. After controlling the influences of confounders - including daily temperature, relative humidity, and atmospheric pressure - an IQR concentrations increase in levels of $\mathrm{SO}_{2}\left(13 \mu \mathrm{g} / \mathrm{m}^{3}\right), \mathrm{NO}_{2}$ $\left(17 \mu \mathrm{g} / \mathrm{m}^{3}\right)$, and $\mathrm{O}_{3}\left(74 \mu \mathrm{g} / \mathrm{m}^{3}\right)$ was associated with $7.8,6.2$, and $5.5 \%$ increases in PHD-related mortality in people age 60 and older, respectively.

Compared to previous reported effects of air pollution on cardiovascular mortality, our analysis reported relatively higher effect estimates for the same level of increase in gaseous pollutants concentration. The risks of PHD-relative mortality for $\mathrm{SO}_{2}$ were approximately 5.5 times greater than those of cardiovascular mortality derived from the Public Health and Air Pollution in Asia (PAPA) project [26], 2.6 times greater for $\mathrm{NO}_{2}$, and 2 times greater for $\mathrm{O}_{3}$. Cao et al. [27] reported that the excess risks of cardiovascular mortality per $10 \mu \mathrm{g} / \mathrm{m}^{3}$ increase in $\mathrm{SO}_{2}$ and $\mathrm{NO}_{\mathrm{x}}$ in China were 4.8 and $2.7 \%$, respectively. The risks of $\mathrm{PHD}$-relative mortality in our study were both 1.3 times greater. Compared to the calculated results of risks of cardiovascular mortality derived from the APHEA (Air Pollution and Health: A European Approach) project [28], those of PHD-relative mortality for $\mathrm{NO}_{2}$ in our study were 9 times greater. Although the results for risks from the aforementioned studies corresponded to the entire population, and those in our studies corresponded to those of only the elderly population, we assumed that the effects of gaseous pollutants on PHD-related mortality might be higher than those on other cardiovascular mortalities. Further studies are warranted to address these differences.

The major sources of gaseous pollutants comprised of $\mathrm{SO}_{2}, \mathrm{NO}_{2}, \mathrm{CO}$, and $\mathrm{O}_{3}$ in Chengdu were mainly from industrial emissions and fuel combustion. In addition, $\mathrm{NO}_{2}$ and $\mathrm{CO}$ can also derive from traffic emissions [29, 30]. The concentrations of gaseous pollutants showed typically seasonal trends in our study. The concentrations of $\mathrm{SO}_{2}, \mathrm{NO}_{2}$, and $\mathrm{CO}$ were remarkably higher 


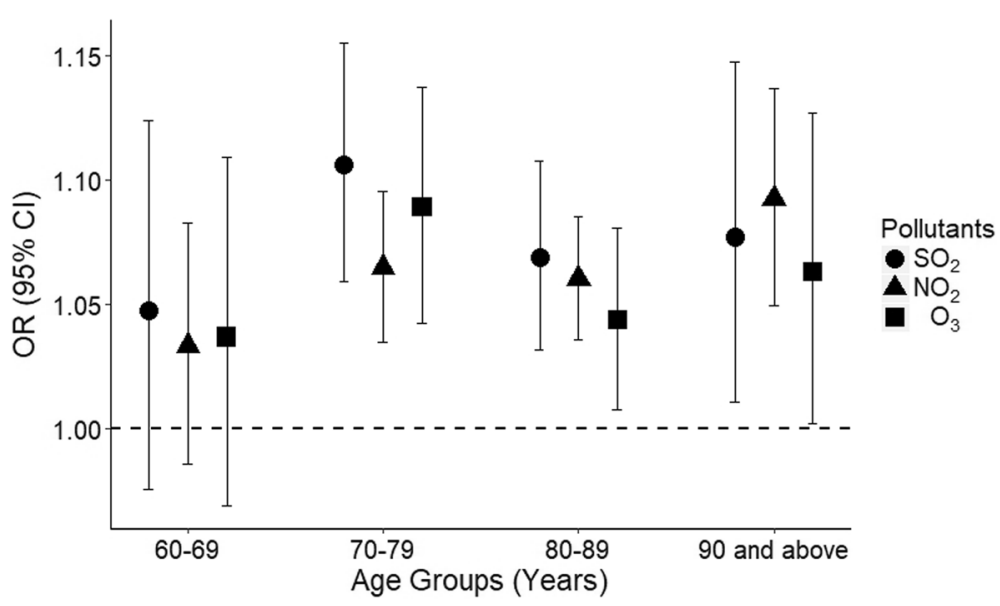

Fig. 3 Association between PHD-related mortality among elderly people and IQR increases for $\mathrm{SO}_{2}, \mathrm{NO}_{2}$, and $\mathrm{O}_{3}$ among different age groups

during winter each year, which may be due to the reduction of air flow diffused dilution efficiency and to the increase of biomass fuel combustion for heating. Higher concentrations of $\mathrm{O}_{3}$ in summer were probably caused by increased sunlight. However, the aforementioned seasonal changes were controlled by using the casecrossover method.

The pathogeny of PHD is multifarious [2]. As confirmed, chronic obstructive pulmonary disease (COPD) is the primary disease leading to PHD, accounting for approximately $80 \%$ of cases [3]. COPD could lead to hypoxic pulmonary vasoconstriction, polycythemia, and destruction of the pulmonary vascular bed [31], while also causing impaired lung function and/or structural damage [32], resulting in pulmonary hypertension [33]. Furthermore, gaseous pollutants-including $\mathrm{SO}_{2}, \mathrm{NO}_{2}$, and $\mathrm{O}_{3}$-have been associated with COPD in short-term exposure studies, longterm exposure studies, and in outdoor or indoor exposure studies [34-36]. These findings might provide a reasonable explanation for the exacerbation of PHD-related mortality in people with COPD with increasing concentrations of gaseous pollutants. The major cause of death associated with PHD was right heart failure [2]. According to previous studies, heart failure-related hospitalization or death was associated with increases in $\mathrm{SO}_{2}(2.36 \%$ per 10 parts per billion) and $\mathrm{NO}_{2}$ (1.70\% per 10 parts per billion) [11]. Thus, increased concentrations of gaseous pollutants might exacerbate PHD-related mortality by inducing heart failure in PHD patients, which might also explain how gaseous pollutants exacerbate PHD-related mortality.

Our study found significant statistical evidence for the modification of PHD-related mortality by age, gender, or marital status. As reported in previous studies, elderly people seemed to have higher susceptibility to mortality caused by gaseous pollutants $[37,38]$, which was in line with our findings. In our study, the association between gaseous pollutants-including $\mathrm{SO}_{2}, \mathrm{NO}_{2}$, and $\mathrm{O}_{3}$-and PHD-related mortality was observed in individuals aged

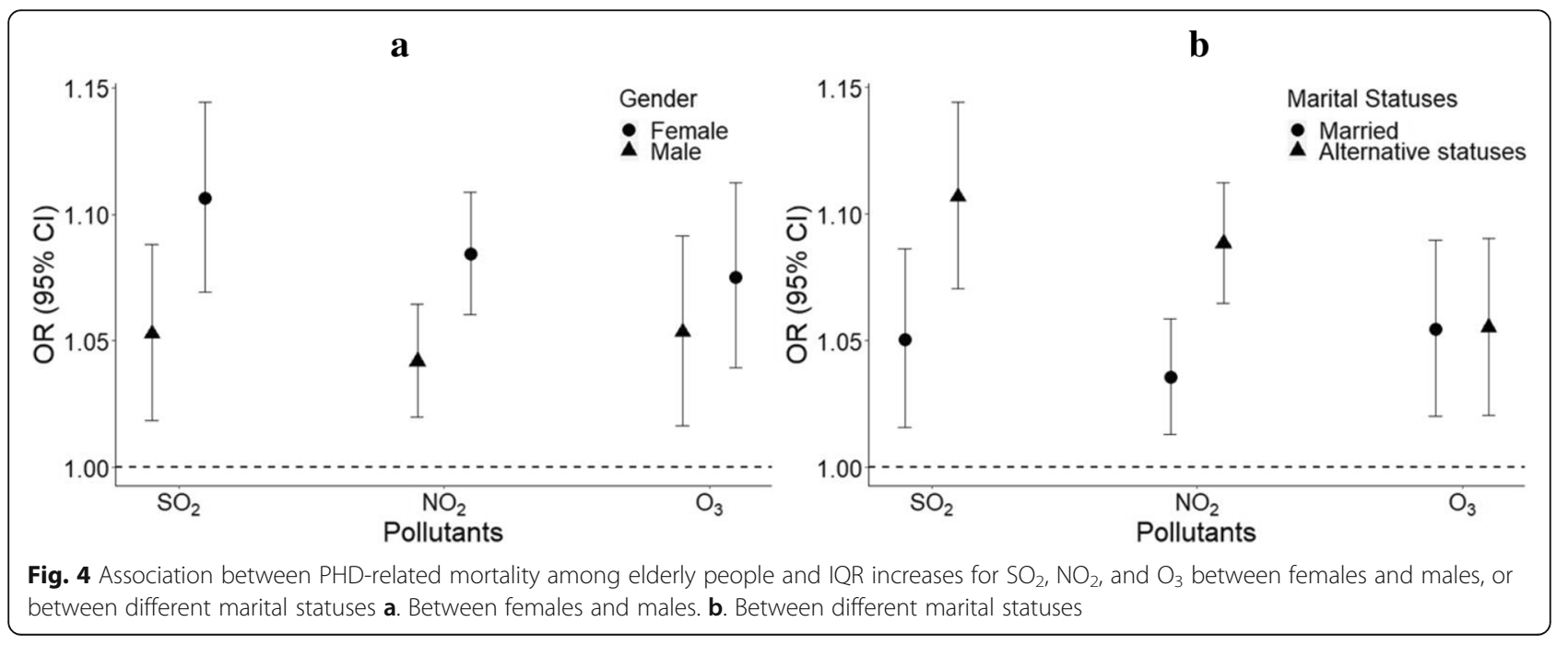


Table 4 Odds ratios (OR) for two-pollutant models including $\mathrm{SO}_{2}, \mathrm{NO}_{2}$, and $\mathrm{O}_{3}{ }^{\mathrm{b}}$

\begin{tabular}{|c|c|c|c|c|}
\hline \multirow{2}{*}{$\begin{array}{l}\text { Air } \\
\text { pollutants }\end{array}$} & & \multirow[t]{2}{*}{ OR } & \multicolumn{2}{|c|}{ OR 95\% Cl } \\
\hline & & & Lower & upper \\
\hline \multirow[t]{5}{*}{$\overline{\mathrm{SO}_{2}}$} & & $1.079^{a}$ & 1.053 & 1.104 \\
\hline & $+\mathrm{PM}_{2.5}$ & $1.062^{\mathrm{a}}$ & 1.031 & 1.093 \\
\hline & $+\mathrm{NO}_{2}$ & 1.020 & 0.986 & 1.055 \\
\hline & $+\mathrm{CO}$ & $1.078^{a}$ & 1.053 & 1.104 \\
\hline & $+\mathrm{O}_{3}$ & $1.075^{a}$ & 1.050 & 1.101 \\
\hline \multirow[t]{5}{*}{$\mathrm{NO}_{2}$} & & $1.062^{\mathrm{a}}$ & 1.046 & 1.078 \\
\hline & $+\mathrm{PM}_{2.5}$ & $1.062^{\mathrm{a}}$ & 1.040 & 1.084 \\
\hline & $+\mathrm{SO}_{2}$ & $1.052^{\mathrm{a}}$ & 1.029 & 1.076 \\
\hline & $+\mathrm{CO}$ & $1.063^{\mathrm{a}}$ & 1.046 & 1.080 \\
\hline & $+\mathrm{O}_{3}$ & $1.060^{\mathrm{a}}$ & 1.044 & 1.077 \\
\hline \multirow[t]{5}{*}{$\mathrm{O}_{3}$} & & $1.055^{\mathrm{a}}$ & 1.031 & 1.080 \\
\hline & $+\mathrm{PM}_{2.5}$ & $1.051^{\mathrm{a}}$ & 1.027 & 1.076 \\
\hline & $+\mathrm{SO}_{2}$ & $1.047^{\mathrm{a}}$ & 1.023 & 1.072 \\
\hline & $+\mathrm{NO}_{2}$ & $1.044^{\mathrm{a}}$ & 1.020 & 1.069 \\
\hline & $+\mathrm{CO}$ & $1.055^{\mathrm{a}}$ & 1.030 & 1.080 \\
\hline
\end{tabular}

Abbreviations: $\mathrm{SO}_{2}$ sulfur dioxide, $\mathrm{NO}_{2}$ nitrogen dioxide, $\mathrm{O}_{3}$ ozone, $\mathrm{OR}$ odds ratio, $\mathrm{Cl}$ confidence interval

${ }^{\mathrm{a}} \mathrm{P}<0.05$

${ }^{\mathrm{b}} \mathrm{ORs}$ for $\mathrm{SO}_{2}, \mathrm{NO}_{2}$, and $\mathrm{O}_{3}$ were from one, one-, and two-day lags, respectively

70 or older but not in those ranging from 60 to 69 years old, indicating that people aged 70 and older might have higher susceptibility to the health effects of gaseous pollutants. Although previous studies found little evidence for a higher occurrence of cardio-respiratory mortality among women than men [39], we determined that females might be more susceptible to PHD-related mortality associated with gaseous pollutants than males. The risk of PHD-related mortality due to exposure to $\mathrm{SO}_{2}$ and $\mathrm{NO}_{2}$ among females was twice that of males. Marital status also could influence health and mortality [40]. In line with previous studies, we found that individuals with alternative marital statuses (widowed, divorced, or never married) had a higher risk of PHD-related mortality due to gaseous pollutants, including $\mathrm{SO}_{2}$ and $\mathrm{NO}_{2}$, than married people. The effect estimates among individuals with alternative marital statuses were more than twice those of married individuals.

According to the results from the two-pollutant models, $\mathrm{NO}_{2}$ and $\mathrm{O}_{3}$ seemed to have more stable health impacts on PHD-related mortality than $\mathrm{SO}_{2}$. After adjusting for another pollutant, the effects of PHD-related mortality caused by $\mathrm{NO}_{2}$ and $\mathrm{O}_{3}$ remained with similar values of ORs calculated from single pollutant models that, when caused by $\mathrm{SO}_{2}$, attenuated to be negative after adjusting for $\mathrm{NO}_{2}$. Renjie Chen et al. [37] suggested that $\mathrm{SO}_{2}$ may serve as a surrogate for other toxic substances correlated with $\mathrm{NO}_{2}$, which may explain how $\mathrm{NO}_{2}$ reduces the association of $\mathrm{SO}_{2}$ with mortality. Thus, $\mathrm{NO}_{2}$ and $\mathrm{O}_{3}$ might merit more attention in regard to their association with PHD due to ambient gaseous pollutants.

In sensitivity analyses, ORs calculated via different lagday structures (Lag01, Lag02, and Lag03, respectively) were similar to those from the single-day lag models (Table 3). The results of the models were reliable.

Our study has three main strengths: First, this is the first study to explore the association between gaseous pollutants and PHD-related mortality in the central Sichuan Basin of southwestern China. Second, mortality data for the whole city were used in our study due to the advantage of the PDIRMS; thus, the data were authentic and reliable. Third, the city of Chengdu is large and densely populated, which is advantageous for performing an ecological study that assesses the effects of air pollutants on health. Our study also has some limitations. First, concentrations of air pollutants were obtained from municipal environmental monitoring sites that are fixed; thus, individual exposure data were not evaluated. Second, this study was conducted in central Sichuan Basin; consequently, the basin's specific geographical features and weather conditions should be considered and generalizations of these results should be treated cautiously. Third, we conducted a time-stratified case-crossover analysis based on individuals from whom cumulative effects could not be obtained.

\section{Conclusion}

Our study found that increased concentrations of ambient $\mathrm{SO}_{2}, \mathrm{NO}_{2}$, and $\mathrm{O}_{3}$ were significantly and positively associated with PHD-related mortality in Chengdu, China. Furthermore, our results suggest that sociodemographic factors - including gender, age, and marital status - may modify the acute health effects of gaseous pollutants. Our study builds evidence for potential health risks from ambient gaseous pollutants.

\section{Additional files}

Additional file 1: Table S1. Spearman's correlation coefficients of air pollutants between individual monitoring sites. (DOCX $37 \mathrm{~kb}$ )

Additional file 2: Figure S1. Seasonal trends of monthly concentrations of $\mathrm{SO}, \mathrm{NO}_{2}, \mathrm{CO}, \mathrm{O}_{3}$, and $\mathrm{PM}_{2.5}$ from 2013 to 2017. (PDF $128 \mathrm{~kb}$ )

\section{Abbreviations}

AP: Atmospheric pressure; Cl: Confidence interval; CO: Carbon monoxide; IQR: Interquartile range; $\mathrm{NO}_{2}$ : Nitrogen dioxide; $\mathrm{O}_{3}$ : Ozone; $\mathrm{O}_{3}-8 \mathrm{~h}$ : Daily eighthour mean concentration for $\mathrm{O}_{3}$; OR: Odds ratio; PHD: Pulmonary heart disease; $\mathrm{PM}_{2.5}$ : Particulate matter less than $2.5 \mu \mathrm{m}$ in aerodynamic diameter; SD: Standard deviation; $\mathrm{SO}_{2}$ : Sulfur dioxide

\section{Acknowledgments}

We thank the Chengdu Municipal Environmental Monitoring Center and the Chengdu Municipal Meteorological Bureau for providing data. 


\section{Authors' contributions}

JYC coordinated the study, performed data analysis, and drafted the manuscript: $\mathrm{JZ}, \mathrm{CLS}$, and RCL contributed to the statistical analyses; RL assisted in obtaining air pollution and health data; SLM coordinated the study and edited the manuscript; and $L Z$ organized and coordinated the study and edited the manuscript. All authors have read and approved the final manuscript.

\section{Funding}

This study was funded by the Special Foundation of Basic Science and Technology Resources Survey of the Ministry of Science and Technology (No. 2017FY101200), the China Short-Term Health Effects of Air Pollution Study (China SHEAP Study; No. 2016YFC0206500), the Sichuan Provincial Medical Research Youth Innovation Project (No. Q17070), and the Sichuan Provincial Cadre Health Care Research Project (No. ZH2018-1801).

\section{Availability of data and materials}

The datasets used in this study are available from the corresponding author upon reasonable request.

\section{Ethics approval and consent to participate}

Not applicable. This study does not involve experimental animals or individual information on human subjects.

\section{Consent for publication}

Not applicable.

\section{Competing interests}

The authors declare that they have no competing interests.

\section{Author details}

'Sichuan Provincial Center for Disease Control and Prevention, No.6, Zhongxue Road, Wuhou District, Chengdu 610041, China. ${ }^{2}$ Chengdu Center for Disease Control and Prevention, Chengdu, China.

Received: 24 December 2018 Accepted: 19 June 2019

\section{Published online: 15 July 2019}

\section{References}

1. Thomas AJ. Chronic pulmonary heart disease. Br Heart J. 1972;34(7):653-7.

2. Weitzenblum E. Chronic COR PULMONALE. Heart. 2003;89(2):225-30.

3. Weitzenblum E, Chaouat A. Cor pulmonale. Chronic Respiratory Disease. 2009;6(3):177-85.

4. MacNee W. Pathophysiology of cor pulmonale in chronic obstructive pulmonary disease. Part one. Am J Respir Crit Care Med. 1994;150(3):833-52.

5. Rigolin VH, Robiolio PA, Wilson JS, Harrison JK, Bashore TM. The forgotten chamber: the importance of the right ventricle. Catheter Cardiovasc Diagn. 1995:35(1):18-28

6. Bloomfield GS, Lagat DK, Akwanalo OC, Carter EJ, Lugogo N, Vedanthan R, Velazquez EJ, Kimaiyo S, Sherman CB. Waiting to inhale: an exploratory review of conditions that may predispose to pulmonary hypertension and right heart failure in persons exposed to household air pollution in lowand middle-income countries. Glob Heart. 2012;7(3):249-59.

7. Butrous $G$, Ghofrani HA, Grimminger F. Pulmonary vascular disease in the developing world. Circulation. 2008:118(17):1758-66

8. Brook RD, Rajagopalan S, Pope CA, Brook JR, Bhatnagar A, Diez-Roux AV, Holquin F, Hong Y, Luepker RV, Mittleman MA, et al. Particulate matter air pollution and cardiovascular disease. Circulation. 2010;121(21):2331-78.

9. Le Tertre A, Medina S, Samoli E, Forsberg B, Michelozzi P, Boumghar A, Vonk $J M$, Bellini A, Atkinson R, Ayres JG, et al. Short-term effects of particulate air pollution on cardiovascular diseases in eight European cities. J Epidemiol Community Health. 2002;56(10):773-9.

10. Pekkanen J, Peters A, Hoek G, Tiittanen P, Brunekreef B, de Hartog J, Heinrich J, Ibald-Mulli A, Kreyling WG, Lanki T, et al. Particulate air pollution and risk of ST-segment depression during repeated submaximal exercise tests among subjects with coronary heart disease: the exposure and risk assessment for fine and ultrafine particles in ambient air (ULTRA) study. Circulation. 2002;106(8):933-8.

11. Shah ASV, Langrish JP, Nair H, McAllister DA, Hunter AL, Donaldson K, Newby DE, Mills NL. Global association of air pollution and heart failure: a systematic review and meta-analysis. Lancet. 2013;382(9897):1039-48.
12. Peters A, Dockery DW, Muller JFE, Mittleman MA. Increased particulate air pollution and the triggering of myocardial infarction. Circulation. 2001; 103(23):2810-5

13. Sandoval J, Salas J, Martinez-Guerra ML, Gómez A, Martinez C, Portales A, Palomar A, Villegas M, Barrios R. Pulmonary arterial hypertension and Cor Pulmonale associated with chronic domestic Woodsmoke inhalation. Chest. 1993;103(1):12-20

14. Sertogullarindan B, Gumrukcuoglu HA, Sezgi C, Akil MA. Frequency of pulmonary hypertension in patients with COPD due to biomass smoke and tobacco smoke. Int J Med Sci. 2012;9(6):406-12.

15. Han L, Zhou W, Li W, Li L. Impact of urbanization level on urban air quality: a case of fine particles (PM2.5) in Chinese cities. Environ Pollut. 2014:194:163-70.

16. Resident Population (Year-end) by region. Sichuan Statistical Yearbook. [http://tjj.sc.gov.cn/tjcbw/tjnj/2017/zk/indexch.htm].

17. (EPA) EPA: National Ambient Air Quality Standards for Ozone: Final Rule. Federal Register 2015, 80(206):65292-65468.

18. Tao Y, Mi S, Zhou S, Wang S, Xie X. Air pollution and hospital admissions for respiratory diseases in Lanzhou, China. Environ Pollut. 2014:185:196-201.

19. Janes H, Sheppard L, Lumley T. Case-crossover analyses of air pollution exposure data: referent selection strategies and their implications for bias. Epidemiology (Cambridge, Mass). 2005;16(6):717-26.

20. Barnett AG, Dobson AJ. Analysing seasonal health data: Springer; 2010.

21. Jung $C R$, Young $L H$, Hsu HT, Lin MY, Chen YC, Hwang BF, Tsai PJ. PM2.5 components and outpatient visits for asthma: a time-stratified casecrossover study in a suburban area. Environ Pollut. 2017;231(Pt 1):1085-92.

22. Guo Y, Tong S, Li S, Barnett AG, Yu W, Zhang Y, Pan X. Gaseous air pollution and emergency hospital visits for hypertension in Beijing, China: a timestratified case-crossover study. Environ Health. 2010;9(1):57.

23. Yang Y, Cao Y, Li W, Li R, Wang M, Wu Z, Xu Q. Multi-site time series analysis of acute effects of multiple air pollutants on respiratory mortality: a population-based study in Beijing, China. Sci Total Environ. 2015;508:178-87.

24. Hastie T, Tibshirani R: Generalized Aditive Models; 1990

25. Zeka A, Zanobetti A, Schwartz J. Individual-level modifiers of the effects of particulate matter on daily mortality. Am J Epidemiol. 2006;163(9):849-59.

26. Wong C-M, Vichit-Vadakan N, Kan H, Qian Z. Public health and air pollution in Asia (PAPA): a multicity study of short-term effects of air pollution on mortality. Environ Health Perspect. 2008;116(9):1195-202.

27. Cao J, Yang C, Li J, Chen R, Chen B, Gu D, Kan H. Association between longterm exposure to outdoor air pollution and mortality in China: a cohort study. J Hazard Mater. 2011;186(2):1594-600.

28. Samoli E, Aga E, Touloumi G, Nisiotis K, Forsberg B, Lefranc A, Pekkanen J, Wojtyniak B, Schindler C, Niciu E, et al. Short-term effects of nitrogen dioxide on mortality: an analysis within the APHEA project. Eur Respir J. 2006;27(6):1129-38.

29. Chen T-M, Kuschner WG, Gokhale J, Shofer S. Outdoor air pollution: nitrogen dioxide, sulfur dioxide, and carbon monoxide health effects. Am J Med Sci. 2007;333(4):249-56

30. Li J, Wang Z, Akimoto H, Yamaji K, Takigawa M, Pochanart P, Liu Y, Tanimoto H, Kanaya Y. Near-ground ozone source attributions and outflow in central eastern China during MTX2006. Atmos Chem Phys. 2008;8(24): 7335-51.

31. Shujaat A, Minkin R, Eden E. Pulmonary hypertension and chronic cor pulmonale in COPD. International journal of chronic obstructive pulmonary disease. 2007:2(3):273-82.

32. Rabe KF, Watz H. Chronic obstructive pulmonary disease. Lancet. 2017; 389(10082):1931-40.

33. S Bloomfield G, K Lagat D, Akwanalo C, Carter EJ, Lugogo N, Vedanthan R, Velazquez E, Kimaiyo S, B Sherman C: Conditions That Predispose to Pulmonary Hypertension and Right Heart Failure in Persons Exposed to Household Air Pollution in LMIC, vol. 7; 2012.

34. Arbex MA, de Souza Conceição GM, Cendon SP, Arbex FF, Lopes AC, Moysés EP, Santiago SL, Saldiva PHN, Pereira LAA, Braga ALF. Urban air pollution and chronic obstructive pulmonary disease-related emergency department visits. J Epidemiol Community Health. 2009;63(10):777-83.

35. Andersen ZJ, Hvidberg M, Jensen SS, Ketzel M, Loft S, Sørensen M, Tjønneland A, Overvad K, Raaschou-Nielsen O. Chronic obstructive pulmonary disease and long-term exposure to traffic-related air pollution. Am J Respir Crit Care Med. 2011;183(4):455-61.

36. Liu Y, Lee K, Perez-Padilla R, Hudson NL, Mannino DM. Outdoor and indoor air pollution and COPD-related diseases in high- and low-income countries 
[state of the art series. Chronic obstructive pulmonary disease in high- and low-income countries. Edited by G. Marks and M. Chan-Yeung. Number 2 in the series]. The International Journal of Tuberculosis and Lung Disease. 2008;12(2):115-27.

37. Chen R, Huang W, Wong CM, Wang Z, Thach TQ, Chen B, Kan H, Group CC. Short-term exposure to sulfur dioxide and daily mortality in 17 Chinese cities: the China air pollution and health effects study (CAPES). Environ Res. 2012;118:101-6.

38. Kan H, London SJ, Chen G, Zhang Y, Song G, Zhao N, Jiang L, Chen B. Season, sex, age, and education as modifiers of the effects of outdoor air pollution on daily mortality in Shanghai, China: the public health and air pollution in Asia (PAPA) study. Environ Health Perspect. 2008;116(9):1183-8.

39. Hoek G, Krishnan RM, Beelen R, Peters A, Ostro B, Brunekreef B, Kaufman JD. Long-term air pollution exposure and cardio- respiratory mortality: a review. Environ Health. 2013:12(1):43.

40. Manzoli L, Villari P, M Pirone G, Boccia A: Marital status and mortality in the elderly: a systematic review and meta-analysis. Soc Sci Med 2007, 64(1):77-94.

\section{Publisher's Note}

Springer Nature remains neutral with regard to jurisdictional claims in published maps and institutional affiliations.

Ready to submit your research? Choose BMC and benefit from:

- fast, convenient online submission

- thorough peer review by experienced researchers in your field

- rapid publication on acceptance

- support for research data, including large and complex data types

- gold Open Access which fosters wider collaboration and increased citations

- maximum visibility for your research: over $100 \mathrm{M}$ website views per year

At $\mathrm{BMC}$, research is always in progress.

Learn more biomedcentral.com/submissions 